\author{
설하선에 발생한 호산성 세포 암종 1 예 \\ 동아대학교 의과대학 이비인후과학교실, ${ }^{1}$ 해부병리학과교실 ${ }^{2}$ \\ 박헌수 $^{1} \cdot$ 김보영 $^{1} \cdot$ 배우용 $^{1} \cdot$ 홍숙희 $^{2}$
}

\title{
A Case of Oncocytic Adenocarcinoma of Sublingual Gland
}

\author{
Heon-Soo Park, MD', Bo-Young Kim, MD ${ }^{1}$, Woo-Yung Bae, MD ${ }^{1}$ and Suk-Hee Hong, MD ${ }^{2}$ \\ ${ }^{I}$ Department of Otolaryngology-Head and Neck Surgery and ${ }^{2}$ Pathology, \\ Dong-A University College of Medicine, Busan, Korea
}

\begin{abstract}
-ABSTRACT -
The oncocytic adenocarcinoma of salivary gland origin is extremely rare. Histopathologic features of this tumor is characterized by oncocytes with marked cellular atypia, frequent mitoses, destruction of adjacent structures, perineural or intravascular invasion and distant or regional metastasis. The treatment is the surgical excision and if there are infiltration of lymph nodes, the neck dissection is recommended. A 55-year-old woman presented with cystic mass on mouth floor for 1 year. The tumor was excised via intraoral approach. Pathologic findings showed that the tumor was lined by proliferated oncocytic cells with atypia and showed infiltrative growth into fibrotic capsule and vascular invasion. We discuss the clinical and histopathological features of the oncocytic adenocarcinoma of the sublingual gland with the review of the literature. (J Clinical Otolaryngol 2004;15:320-322)
\end{abstract}

KEY WORDS : Oncocytic adenocarcinoma $\cdot$ Sublingual gland.

\section{서론}

타액선에 발생하는 호산성 세포 암종(oncocytic adenocarcinoma) 은 매우 드문 종양으로 전체 타액선 종양 중 $0.1 \%$ 이하를 차지하며 이하선에서 주로 발생한다. ${ }^{1)}$ 이하선 외에 후두, 기관, 기관지, 식도, 비강점막, 갑상선, 부갑상선, 췌장, 위, 간 등에 드물게 발생할 수 있다. ${ }^{2)}$ 병 리조직검사상 이 종양은 이형성( aty pia) 을 보이는 호산성 과립세포(oncocy te), 유사분열, 신경주위 및 혈관 침윤,

논문접수일 : 2004년 9월 18일

심사완료일 : 2004년 10월 30일

교신저자 : 박헌수, 603- 102 부산광역시 서구 동대신동 3

가 1 동아대학교 의과대학 이비인후과학교실

전화 : (051) 240- 5428. 전송 : (051) 253- 0712

E-mail : autumn108@ hanmail.net
국소 림프절 및 원위부 전이의 특성을 보인다. ${ }^{12)}$ 치료는 초기의 외과적 절제가 우선이며,-3)7) 원위부 전이가 가 장 중요한 예후 인자이다. ${ }^{4)}$ 최근 저자들은 아직 국내에 보고 된 바가 없는 설하선에 발생한 호산성 세포 암종 1 예를 치험하였기에 문헌 고찰과 함께 보고하는 바이다.

\section{증 례}

55세 여자 환자가 1년전부터 점차 커지는 좌측 구강 저의 종물을 주소로 내원하였다. 내원시 종물은 좌측 구 강저에 위치하고 있었고, $3 \times 3 \mathrm{~cm}$ 크기로 검붉은 색을 띄고 있었다. 촉진시 표면은 매끄러운 낭성의 촉감이었 고 압통은 호소하지 않았다. 경부 림프절은 촉지되지 않 았다. 과거력에서 2년전 진단받은 우울증으로 정신과에 서 신경안정제 복용중이었고, 다른 질병이나 가족력은 없 었다. 본원 내원 일주일 전 다른 병원에서 종양으로부터 
Fig. 1. MRI findings of the case. A : T2-weighted axial image shows oval mass on left mouth floor. B : Enhanced T2-weighted axial image shows enhanced fluid in mass and partial rim enhancement.

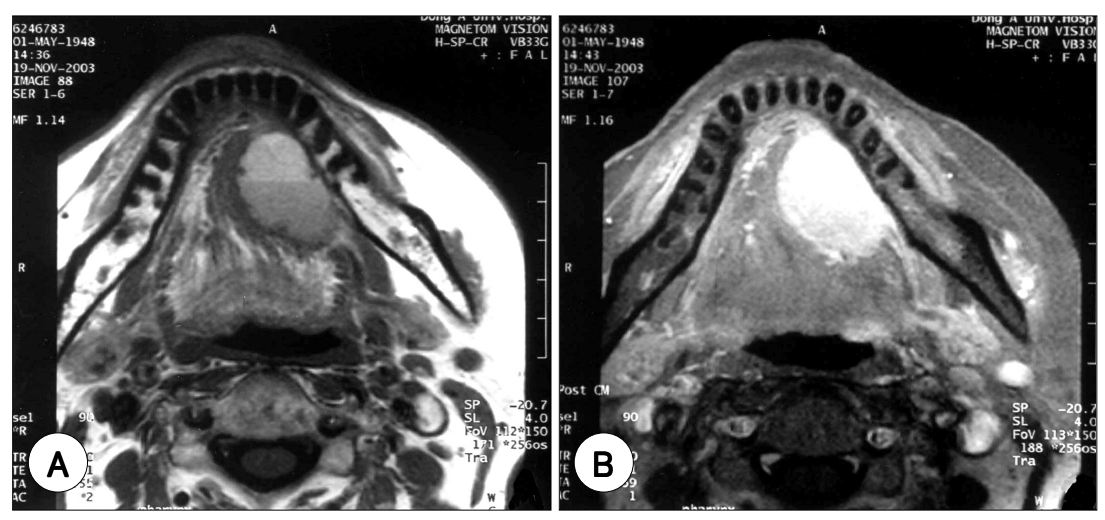

Fig. 2. Histologic findings of the case. A : The tumor shows capsular and vascular invasion ( $H$ \& E stain, $\times 40$ ). $B$ : The tumor cells show nuclear atypia with large nuclei, abundant acinophilic cytoplasm and mitotic figures ( H \& E stain, $\times 200$ ).
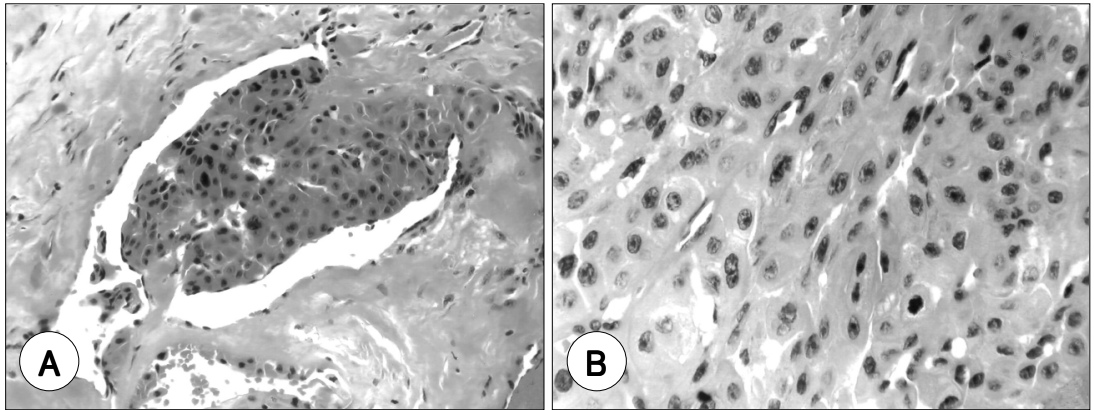

$5 \mathrm{cc}$ 가량의 황색 점액성분을 흡인한 적이 있었다. 본원 에서 촬영한 인두부 자기공명영상에서 좌측 구강저에 $2.5 \times$ $2.5 \mathrm{~cm}$ 크기의 낭성 종괴가 관찰되었고, T 2 강조영상에 서 높은 신호를 보이는 액체 저류 소견을 보였다. 조영 스캔에서 종괴의 가장자리를 따라서 부분적으로 선형 조 영 증강소견을 보였다(Fig. 1). 술 전 세침 흡인 세포 검 사상에는 다수의 대식세포만 관찰되었다. 2003년 12월 1 일 전신마취하에 종물 적출술을 시행하였다. 좌측 설하 선에서 기원한 $3 \times 3 \mathrm{~cm}$ 크기의 낭성 종물을 악하선관 과 설신경 손상없이 좌측 설하선과 함께 완전 적출 하였 다. 조직병리검사에서 적출한 종물은 $0.1 \mathrm{~cm}$ 두께의 얇 은 벽을 가진 낭성 종양이었으며 낭 내벽에는 혈괴와 함 께 회백색의 유두상 성장을 보이는 다수의 고형 조직이 붙어 있었다. 고형부의 종양세포는 뚜렷한 핵소체를 가 진 핵이 관찰되었고, 다소 풍부한 호산성의 세포질을 보 였다. 핵의 크기는 다양하였으며, 중정도의 다형성을 보 였고 소수의 유사분열이 관찰되었다. 종양세포는 일부 주 변 피막 및 혈관으로의 침윤 소견을 보여 설하선에 발생 한 호산성 세포 암종으로 진단되었다Fig. 2). 술 후 합
병증 없이 퇴원하였고, 복부 초음파 검사 및 방사선 동 위원소 전신 골주사 촬영에서 전이 소견 관찰되지 않았 다. 술 후 좌측 설하선 부위에 $5400 \mathrm{cGy}$ 의 방사선 치 료를 실시하였으며, 술 후 9 개월째 추적 관찰한 결과 재 발의 증후는 없었다.

\section{고 찰}

호산성 세포종는 성인에 호발하는 종양으로 타액선 종 양의 $1 \%$ 이하를 차지하며 주로 이하선에서 발생하고 양 측성으로 생길 수 있다. 다른 타액선 및 비강, 후두, 편 도와, 누귀(lacrymal caruncle), 협점막(buccal mucosa) 등에서도 발생할 수 있다. 타액선에서 호산성 과립세포 는 주로 50대 이후에서 관찰되는데, 이는 나이가 증가 함에 따라 타액선 상피세포와 선방세포가 호산성 세포로 전환하기 때문인데, 이 과정은 비정상적인 미토콘드리아 대사과정(abnormal mitochondrial metabolism) 으로 간 주되고 있다. ${ }^{2)}$ 호산성 세포종 중에서 호산성 세포 암종은 1953년에 처음 보고되었다. ${ }^{5)}$ 이하선에서 주로 발생하고 
연구개, 상종격동, 기관지, 사골동( ethmoid sinus), 상악 동, 누낭 (lacrimal sac) 등에서도 발생할 수 있고, 전체 타액선 종양의 $0.1 \%$ 이하를 차지한다. ${ }^{1)}$ oncocytic adencarcinoma라는 용어는 oncocy tic carcinoma, malignant oncocy toma, maliganant oxyphillic adenoma와 동의어로 사용된다. ${ }^{1)}$ 병리조직 소견상 호산성 세포 성분 이 바탕을 이루면서 세포의 이형성, 유사분열, 주변 조직 의 파괴, 주변 신경 및 혈관 침윤, 인접 림프절 및 원위 부 전이를 보일 때 호산성 세포성 암종으로 진단된다. ${ }^{1-3)}$ 병리조직상 감별진단 해야 할 질환으로는 salivary duct carcinoma, 선방세포암종( acinic cell carcinoma), 고도 의 점액표피양암종 (high grade mucoepidermoid carcinoma), Warthin 종양과 갑상선, 신장, 유방, 간 등으 로부터의 전이암 등이다. ${ }^{3)}$ 1998년 Nakada 등 ${ }^{4)}$ 은 27 명 의 oncocytic adenocarcinoma중 국소 림프절 전이는 17 명(63.0\%), 원위부 전이는 7명(25.9\%) 로 보고하고 있고, 국소 림프절 전이는 병의 예후에 결정적인 인자가 되지 못하고 원위부 전이 여부가 가장 중요한 예후 인자 라고 하였다. 원위부 전이 장소는 폐가 가장 흔하다. ${ }^{6)}$ 원 발 종양의 크기는 중요한 예후 인자로 종양의 직경이 2 $\mathrm{cm}$ 보다 작으면 예후가 좋은 것으로 보고하였다. ${ }^{7)}$ Baisakis 등 ${ }^{8)}$ 은 종양의 위치도 예후인자의 하나로써 비강, 부비동, 후두에 발생하는 경우 더욱 침습적이라고 보고 하였으나, Goode 등 $^{7)}$ 은 종양의 위치와 성별은 예후와 상 관없다고 보고하였다. 1998년 Goode와 Corio는 9명의 타액선에 발생한 호산성 세포 암종을 보고하였고, 이들 중 5 명 $55.6 \%)$ 은 재발하였고, 이 중 4 명은 초기의 적극 적인 외과적 조치를 하지 않았다고 보고하였다. ${ }^{7)}$ 치료는 초기의 적극적인 수술적 절제가 최선이다. ${ }^{1-3) 7)}$ 국소 림
프절 전이가 있을 때는 경부 절제술을 함께 실시하여야 한다. ${ }^{1)}$ 7) 국소 림프절 전이가 없을 때는 원발 부위가 침 습적 성질이 강하거나, 국소 림프절 전이가 강하게 의심 될 때는 국소 경부 절제술이 고려될 수 있으나, ${ }^{27)}$ 원발 부위의 직경이 $2 \mathrm{~cm}$ 이하일 경우는 예방적 경부 절제술 은 추천되지 않는다. ${ }^{1)}$ 술 후 방사선 치료나 항암치료를 시행할 수는 있으나 아직 확립된 근거는 없다. ${ }^{2) 7)}$ 종양의 재발은 걱정되는 임상적 특징 중 하나로 초기에 불완전 하게 외과적 절제를 한 경우에 많이 발생하며, 재발된 암 의 대부분에서 전이가 동반된다. ${ }^{7)}$

중심 단어 : 호산성 세포 암종 설하선.

\section{REFERENCES}

1) Cinar U, Vural C, Basak T, Turgut S. Oncocytic carcinoma of the parotid gland: report of a new case. Ear Nose Throat J 2003;82:699-701.

2) Gavilanes J, Perez CA, Brandariz JA, Domingo C, Garcia A, Zajchowski J, et al. Malignant oncocytoma of a minor Salivary gland: an unusual presentation at the base of the tongue. ORL J Otorhinolaryngol Relat Spec 2000;62:104-8.

3) Gupta S, Sodhani P. Malignant oncocytoma of a submandibular salivary gland. Acta Cytol 2000;44:492-3.

4) Nakada M, Nishizaki K, Akagi H, Masuda Y, Yoshino T. Oncocytic carcinoma of the submandibular gland: a case report and literature review. J Oral Pathol Med 1998;27: 225-8.

5) Bauer WH, Bauer JD. Classification of glandular tumors of salivary glands: study of one-hundred forty-three cases. AMA Arch Pathol 1953;55:328-46.

6) Johns ME, Regezi JA, Batsakis JG. Oncocytic neoplasms of salivary glands: an ultrastructural study. Laryngoscope 1977; 87:862-71.

7) Goode RK, Corio RL. Oncocytic adenocarcinoma of Salivary glands. Oral Surg Oral Med Oral Pathol 1988;65:61-6.

8) Baisakis JG, Regezi JA. Selected comtroversial lesions of salivary tissues. Otolaryngol Clin North Am 1977;10:309-27. 